\title{
ISWIMAN - Integrated Sustainable Wildlife Management - Principles, Criteria and Indicators for Hunting, Forestry, Agriculture, Recreation
}

\author{
Friedrich Reimoser ${ }^{1 *}$, Wolfgang Lexer², Christiane Brandenburg ${ }^{3}$, Richard Zink ${ }^{1}$, Felix Heckl² ${ }^{2}$ Andreas Bartel ${ }^{2}$ \\ ${ }^{* 1}$ Department of Integrative Biology and Evolution, University of Veterinary Medicine, Austria \\ ${ }^{2}$ Austrian Environment Agency, UBA, Vienna \\ ${ }^{3}$ University of Natural Resources and Life Sciences, Vienna
}

Submission: March 08, 2021; Published: March 15, 2021

"Corresponding author: Friedrich Reimoser, Department of Integrative Biology and Evolution, University of Veterinary Medicine, Vienna, Austria. Email : friedrich.reimoser@vetmeduni.ac.at

\begin{abstract}
Tools for an integral sustainability assessment of four different land user groups have been developed in the Austrian model region "ViennaWoods Biosphere Reserve". Focusing on the cross-cutting issue of wildlife management, the step from sector-specific towards cross-sectoral integrated assessment of sustainable use has been taken for the first time. The assessment tools are also suitable for wider application if indicators are adapted to the specific region.
\end{abstract}

Keywords: Land use, Wildlife, Sustainability, Indicators, Assessment, Method

\section{Study outline}

Wild animals and their habitats are exposed to multiple impacts caused by hunting and many other often overlapping and competing land-use activities within the wildlife habitat. Standalone sectoral approaches to sustainable use are insufficient and often result in unintended adverse effects on other land-use sectors and the relevant ecosystems. In contrast, sustainable wildlife management requires that all land-user groups in the wildlife habitat are aware of and consider the effects of their activities on both wildlife resources and other user groups [1-3].

With this in mind, concepts and tools for the integrated sustainability assessment of several land-user groups have been developed in the model region "Vienna Woods Biosphere Reserve". The Biosphere Reserve is an intensively used area for a variety of activities sited near to Austria`s capital Vienna, and (as specifically envisaged for biosphere reserves) the main aim is the development and implementation of sustainable land-use concepts. Applied and participatory research methods have been used to identify, analyse and evaluate key interfaces and linkages (both antagonistic and synergistic) between wildlife populations, wildlife habitats and different forms of regional land use. The main project outputs are four operational sets of principles, criteria and indicators for integrated sustainable wildlife management, focused on the major regional land-user groups forestry, agriculture, hunting, and recreational management.

These four assessment sets are harmonised across the land-use sectors and designed as self-evaluation tools; they are to be applied by each of the four land-user groups in order to evaluate their respective influence on the sustainable conservation of wild animal species, their habitats and sustainable hunting. The assessment framework of each group also considers relevant sustainability requirements of other user groups. Recommendations for integrated sustainable wildlife management and for respective monitoring have been elaborated. Project results should contribute to the avoidance, mitigation and resolution of wildlife land-use conflicts and to the integration of wild animals and their management into a sustainable regional land-use system. The land-user groups of the model region comprise private, community, and public organizations. The publication including the assessment sets as annexes, is available for download at the homepage of the Austrian Academy of Sciences [4]. The assessment tools are also suitable for wider application if indicators are adapted to the specific region. 


\section{Structure and functioning of the assessment}

In order to integrate wild animals into overall sustainable land use in line with the requirements of nature conservation, the term "integrated sustainable wildlife management" (including wildlife populations and their habitats) was coined. They are given life and substance through the Assessment Set of Principles, Criteria and Indicators, involving ecological, economic, and socio-cultural aspects.

The sustainability assessment is made via questions that assign point scores to indicators. If readers/users decide to take a short cut to the indicators, they need to be aware of the content of the criterion which the indicator addresses, as well as of the content of the governing principle, before making an evaluation. Also, they need to be clear to which aspect of sustainability the respective principle, criterion and indicator belongs (ecological, economic or socio-cultural). This is the only way assessment questions for the indicators can be correctly interpreted. Each of the structural levels (principle, criterion and indicator) gives additional information and offers explanations which tend to be important for understanding the assessment questions. The assessment framework serves the purpose of a voluntary examination of the sustainability of wildlife management through self-assessment. On the basis of the list of assessment criteria, the degree of sustainability of one's own practice of land use can be evaluated, in order to identify its strengths and weaknesses and to provide assistance for decisions in favour of a more sustainable future practice of land use, if such decisions need to be made.

The assessment considers a variety of activities of the land user group addressed by the respective set, as well as wild animals subject to hunting law. In the sets of the user groups of forest management, agriculture and leisure and recreation management, the assessment further refers to the interfaces with sustainable hunting practice. The set for hunting also addresses interfaces with the other three sectors. Animal species not subject to hunting laws that closely interact with wildlife species relevant in terms of hunting law are touched upon but are not immediate subjects of the assessment. The prevailing spatial unit assessed is the management area of the respective group. In principle, however, the assessment is also applicable to larger territorial units. The period of assessment is the current or preceding calendar year. In some cases, longer periods of time are chosen. Ideally, the sustainability assessment ought to be based on a management concept existing in writing or in thought (management plan, operating protocol, hunting code of practise, etc.). For each of the four sets, a different overall number of principles (p), critereia (c) and scored indicators (i) were defined: hunting $14 \mathrm{p}, 25 \mathrm{c}$ and $56 \mathrm{i}$, forest management $11 \mathrm{p}, 18 \mathrm{c}$ and $42 \mathrm{i}$, agriculture $11 \mathrm{p}, 17$ $\mathrm{c}$ and $28 \mathrm{i}$, leisure and recreation management 9 p, $17 \mathrm{c}$ and 35 i. The assessment framework has the hierarchical structure of a tree with branches which, starting from the level of principles and criteria, increasingly branch out downward to the indicators. Within each sector, principles are made operative with a certain number of criteria, and these in turn through a certain number of indicators. Thus, the degree of specificity and targeting of actions increases from the top of the assessment pyramid towards the base. The actual assessment is made at the lowest level, that of the indicators, through a system of point scores.

\section{Outlook}

The project results are meant to raise general awareness of the need for integrated management of sustainable use of natural resources, and to establish links and connections between ecological, economic and socio-cultural aspects. This requires public relations work and the systematic transfer of results to organisations for the respective user groups. There is the possibility of creating an internet-based option for interactive electronic self-assessment, and for application of the assessment tool to other regions using adapted indicators (http://selbsttest. biologischevielfalt.at). A continuation of the "Inter-sectoral Forum for Conflict Management," a stakeholder platform established in the course of the ISWIMAN project, is strived for. For a potential large-scale objective external assessment of sustainability, the development of additional monitoring systems is necessary. Supra-regional comparisons are ideally carried out within the scope of internationally harmonised and agreed programmes, depending on the individual wildlife species (e.g., populations, migration flyways).

\section{Acknowledgements}

The Project was supported by the Man and Biosphere (MaB) Programme of the Austrian Academy of Sciences, and by the IUCN Sustainable Use Specialist Group.

\section{References}

1. Reimoser F, Lexer W, Forstner M, Hackl J, Heckl F (2003) Kriterien und Indikatoren einer nachhaltigen Jagd. Zeitschrift für Jagdwissenschaft 49: 275-287.

2. Lexer W, Reimoser F, Hackl J, Heckl F, Forstner M (2005) Criteria and indicators of sustainable hunting - the Austrian assessment approach. Wildl. Biol. Pract. 1(2): 163-183.

3. Reimoser F (2012) Towards integrated wildlife management in the Vienna Woods. IUCN, SULi News (2): pp. 2.

4. Reimoser F, Lexer W, Brandenburg Ch, Zink R, Heckl F, et al., (2013) Integrated Sustainable Wildlife Management - Principles, Criteria and Indicators for Hunting, Forestry, Agriculture, Recreation. $\left(2{ }^{\text {nd }}\right.$, improved edition), Austrian Academy of Sciences, Vienna, Austria, pp. 280 (including 4 annexes). 
CC Co This work is licensed under Creative
Commons Attribution 4.0 License
DOl:10.19080/ARTOAJ.2021.25.556312
Your next submission with Juniper Publishers will reach you the below assets

- Quality Editorial service

- Swift Peer Review

- Reprints availability

- E-prints Service

- Manuscript Podcast for convenient understanding

- Global attainment for your research

- Manuscript accessibility in different formats ( Pdf, E-pub, Full Text, Audio)

- Unceasing customer service

Track the below URL for one-step submission https://juniperpublishers.com/online-submission.php 